\title{
Association between Malnutrition and Cognitive Impairment among Morocco's Older Adults
}

\author{
Abdeljalil Talhaoui*, Youssef Aboussaleh, Ahmed Ahami, Rachid Sbaibi, Naima Agoutim \\ Behavioral Neuroscience \& Nutritional Health Team, Laboratory of Nutrition \& Health, Department of Biology, \\ Faculty of Sciences, Ibn Tofail University, Kenitra, Morocco \\ Email: AAbdeljalil_Talhaoui@outlook.com, abou_85@yahoo.fr,ahami_40@yahoo.fr, sbai75@hotmail.com, \\ naima.agoutim.nchsp@gmail.com
}

How to cite this paper: Talhaoui, A., Aboussaleh, Y., Ahami, A., Sbaibi, R. and Agoutim, N. (2019) Association between Malnutrition and Cognitive Impairment among Morocco's Older Adults. Open Journal of Medical Psychology, 8, 1-14. https://doi.org/10.4236/ojmp.2019.81001

Received: December 24, 2018

Accepted: January 27, 2019

Published: January 30, 2019

Copyright $\odot 2019$ by author(s) and Scientific Research Publishing Inc. This work is licensed under the Creative Commons Attribution International License (CC BY 4.0).

http://creativecommons.org/licenses/by/4.0/

\begin{abstract}
Objective: The aim of this study was to determine the association between the malnutrition and risk of cognitive impairment among Morocco older adults. Materials and methods: A sample of 237 older adults aged above 60 years were recruited from three nursing homes belonging to three different cities, Rabat, Kenitra and Sidi Kacem City and from one health center in Sidi Kacem City. From them, 172 subjects $(56.4 \%$ men) were included in our study for their completion. Cognitive functions were assessed by the Mini-Mental State Examination. Nutritional status, depression and physical activity were assessed using respectively: MNA, GDS-15 and GPAQ. The binary logistic regression was performed where the cognitive function was taking as the dependent variable and all other outcomes as independent variables. Results: Our results showed that $69.8 \%$ of total simple were classed as having cognitive impairment while only $30.2 \%$ were normal. The binary logistic regression assessed showed that the malnutrition ( $\mathrm{OR}=3.03,95 \% \mathrm{CI}: 1.34-6.85)$, gender $(\mathrm{OR}=2.22,95 \%$ CI: 1.03 - 5.71) and low education ( $\mathrm{OR}=8.35,95 \%$ CI: 1.32 - 52.83) were risk factors for cognitive impairment, when moderate level of physical activity $(\mathrm{OR}=0.19,95 \% \mathrm{CI}: 0.06-0.54)$ was a protective factor compared to the limited level. Conclusions: Our study supported past literature that malnutrition and low level of physical activity were risk factors of cognitive impairment. These indicate that nutritional status monitoring and the practice of regular physical activities can prevent it from leading to Alzheimer's disease.
\end{abstract}

\section{Keywords}

Cognitive Impairment, Cognitive Function, Malnutrition, Older Adults 


\section{Introduction}

In Morocco according to Directorate of Statistics of the High Commission for Planning (HCP), the percentage of the population aged over 60 years was $8.1 \%$ and $9.4 \%$ respectively in 2004 and 2014 and would reach $23.2 \%$ of the total population, from 3.2 million in 2014 to 10.1 million by 2050 [1]. This rapid increase of the older population requires more studies on this category, their physical health, mental health as well as their nutritional status. This is for two essential objectives: to put a maximum of available data for people to make decisions, and to study the risk factors on which we can act in order to ensure the elderly population aging success.

Aging is characterized by physiological and psychological changes induced by genetic factors, called intrinsic factors and environmental factors, called extrinsic, on which various pathologies are added to accelerate the aging process [2]. The latter two factors (extrinsic and pathological) represent the most modifiable target we can act on to slow down the effects of aging and preserve the maximum independence of the elderly.

The elderly are particularly vulnerable to nutritional change deficits [3]. Around the world malnutrition has been reported to affect $3.2 \%$ to $17 \%$ of community living elderly people [4] [5] from $12.6 \%$ to $25.7 \%$ in nursing homes [6] [7]. Protein-energy malnutrition results from an imbalance between intake and body requirements. This imbalance causes tissue loss, in particular muscle tissue, which can worsen the prognosis of underlying diseases and increased risks of death and institutionalization [8] [9].

Aging is confirmed to be associated with the progression of cognitive decline, which can be convert in $8.3 \%$ of cases to Alzheimer's disease per year [10] [11]. Alzheimer's disease (AD) is a neurodegenerative disease characterized by memory loss and cognitive and behavioral disorders with repercussions on the daily life of patients [12]. Some causes know to lead to $(\mathrm{AD})$ : a neurofibrillary protein called tau protein abnormally phosphorylated causes his intracellular accumulation. Another accumulation in extracellular area is of $\beta$-amyloid peptide $(\mathrm{A} \beta)$ at the senile plaques [13]. The formation of $\beta$-amyloid peptide $(\mathrm{A} \beta)$ is generally due to mutations of PSEN1 (69\%), APP (13\%), APP (7.5\%), duplication, and rarely due to mutations of PSEN2 (2\%), which are responsible for an early age of onset of $\mathrm{AD}$, in general before 60 years [14] [15]. PS1 or PS2 genes, code for presenilin proteins that are part of gamma secretase complex (g-secretase complex), cleaving APP (amyloid precursor protein) at the C-terminal level from Abeta [16]. the $\varepsilon 4$ allele which is associate with late sporadic $\mathrm{AD}$ (after 60 years), localized on chromosome 19 code for apolipoprotein $\mathrm{E}$, protein involved in the transport of blood lipids and enter in link with $\mathrm{A} \beta$ for the formation of senile plaques [15] [17]. The extracellular formation of senile plaque and intracellular accumulation causes lesions that preferentially affecting the limbic system responsible for memory loss, but also the neocortex [18].

Memory deficit or mild cognitive impairment (MCI) is one of the earliest and most pronounced symptoms of $\mathrm{AD}$ [19]. At This stage the population may con- 
stitute, a particularly suitable population for preventive approaches, and clinical trials of drug therapies [11]. By 2050 cognitive impairment including MCI is expected to affect 115 million people in the world [20]. The Mini-Mental State Examination (MMSE) represents the most used tool in world elaborated by Folstein et al. in 1975 to assess global cognitive impairment with specificity and sensitivity $82 \%$ and $87 \%$ respectively [21]. The MMSE is a brief test that takes a few minutes in its execution. It is composed of a series of questions grouped into 7 subtests. The questions relate to: orientation in time, orientation in space, immediate recall of three words, attention, delayed recall of three words, language and constructive praxis [22].

Many studies has been linked an association between cognitive function and nutritional status explored by MNA [23] [24]. In a cross-sectional study performed by El Zoghbi et al., in three long-stay elderly institutions in Beirut among 111 elderly (55 men and 56 women), showed that cognitive state of elderly was only explained by lower nutrition status $(\mathrm{ORa}=3.03)$ and education $(\mathrm{ORa}=1.72)[6]$. To our knowledge, no one like those studies was conducted in Morocco country. The aim of this study was the identification the link between nutritional status and cognitive state among the elderly population living in three cities (Rabat, Kenitra and Sidi Kacem City) in north oust of Morocco.

\section{Materials and Methods}

\subsection{Participants}

In this cross-sectional study that was conducted between March 2017 and May 2018, All participants were recruited from three nursing home belong to three different cities Rabat, Kenitra and Sidi Kacem City and from one Health center in Sidi Kacem City. The 3 cities are located in north-oust of Morocco. The raisons for choosing nursing home and free living participants were to have more representative simple and because the prevalence of cognitive impairment was anticipated to be more frequent among nursing home elderly. The subjects were excluded from the study if showing one of those following criteria: 1) age below 60 years. 2) Subjects with renal insufficiency which could confounder and overestimate the body mass index. 3) Persons with acute pain that could influence their performance on MMSE test. At beginning 237 subjects were recruited for this study, but after excluding 65 subjects with missing data (65 subjects for MMSE, 5 subject for MNA and 4 subjects for physical activity missing data), 172 subjects were included in our study for their complete data.

Demographic data and medical conditions were obtained from social and medical assistance in nursing homes and by direct interview with patients visiting health centre in Sidi Kacem City. Oral consent was obtained from each participant before be including in this study.

\subsection{Measurements}

Nutritional status of our simple was evaluated by Mini nutritional assessment 
(MNA), tool developed by Guigoz et al., and recommended by the ESPEN (European Society for Clinical Nutrition and Metabolism) [25] [26]. It is composed of 18 items grouped in four sections: anthropometric assessment (weight, height and weight loss); general assessment (living situation, number of medicine use, mobility); dietary assessment (number of meals, food and fluid intake, and autonomy of feeding), and subjective assessment (self-perception of nutritional status and health) [5]. A total score ranges from 24 to 30 reflects good nutritional status. Score between 17 and 23.5 indicates a risk of malnutrition. MNA score $<17$ points indicates malnutrition [27].

\subsection{Cognitive Function Evaluation}

Cognitive function was assessed with the MMSE. With a cut-off of 24, the elderly were classified into two categories: Normal or cognitive impairment.

\subsection{Psychological Evaluation}

The Geriatric depression scale-15 (GDS-15) was used to evaluate the depressive syndrome among elderly participants, with score maximal of 15 points. A score between 5 and 12 were used to indicate slight depression and score $>12$ for severe depression [28].

\subsection{Physical Activity Evaluation}

The GPAQ (global physical activity questionnaire) is one of validated questionnaire developed by the WHO to assess physical activity (PA) in developing countries [29]. The questionnaire composed of 16 items, collecting information about vigorous and moderate intensity PA, covering three domains: Working (paid or unpaid) commuting (walking or cycling) and leisure times [30]. According to the norms recommended by the WHO for this tool, the participants' were classified into 3 levels:

High level:

$\checkmark$ If the person practices vigorous intensity physical activity on at least three days with an expending of 1500 MET-minutes a minimum per week.

$\checkmark$ If the person practices seven or more days of walking, moderate- or vigorous-intensity activities with an expending a minimum of 3000 MET-minutes per week.

Moderate level:

$\checkmark$ If the subject practices at least 20 minutes per day of vigorous-intensity activity three or more times per week.

$\checkmark$ At least 30 minutes per day of moderate-intensity activity or walking five or more times per week.

$\checkmark$ Five or more days of walking, moderate- or vigorous-intensity activities expending a minimum of 600 MET-minutes per week.

Low level:

The subject considered as having low level of PA if don't meet any of above criteria. 


\subsection{Statistical Analysis}

Statistical analysis was performed using software SPSS version 24. Student's T-test was used for comparison of quantitative variables between two groups, for those follow a normal distribution, Mann-Whitney test for those has no normal distribution. The Chi-square test was used to analyze the association between categorical variables. Pearson and spearman tests were used to analyze the correlation between tow quantitative variables normally and no normally distributed respectively.

The binary logistic regression was applied, in which cognitive status was taking as the dependent variable and others variables as independent variables. At $\mathrm{P}$-value $<0.05$ was considered significant for all analysis.

\section{Results}

\subsection{Baseline Characteristics According to Gender}

The distribution of all characteristics included in this study according to gender is shown in Table 1. Compared to the men, women are more likely to be in low level of education ( $\mathrm{P}=0.047)$, more likely to be Widowed $(\mathrm{P}<0,001)$, never practiced some profession $(\mathrm{P}<0.001)$, without pension $(\mathrm{P}=0.048)$, women are also more likely to have hypertension $(\mathrm{P}=0.037)$ and depression $(\mathrm{P}=0.045)$. On the other hand men are more likely to have dental problems to use smoking. There was no significant difference for all other variables between women and men.

Table 1. Baseline characteristics according to gender.

\begin{tabular}{|c|c|c|c|c|}
\hline & $\begin{array}{c}\text { Total } \\
\mathrm{N}=172\end{array}$ & $\begin{array}{c}\text { Females } \\
\mathrm{N}=75 \\
(43.6 \%)\end{array}$ & $\begin{array}{c}\text { Males } \\
\mathrm{N}=97 \\
(56.4 \%)\end{array}$ & $P$ value \\
\hline \multicolumn{5}{|l|}{ Age } \\
\hline Mean \pm SD & $67.53 \pm 7.53$ & $67.56 \pm 8.36$ & $67.52 \pm 6.87$ & 0.588 \\
\hline \multicolumn{5}{|l|}{ Living place } \\
\hline Free living & $96(55.8 \%)$ & $38(50.7 \%)$ & $58(59.8 \%)$ & 0.232 \\
\hline In nursing home & $76(44.2 \%)$ & $37(49.3 \%)$ & $39(40.2 \%)$ & \\
\hline \multicolumn{5}{|l|}{ Education } \\
\hline Low N (\%) & $147(85.5 \%)$ & $69(92.0 \%)$ & $78(80.4 \%)$ & 0.047 \\
\hline Intermediate $\mathrm{N}(\%)$ & $22(12.8 \%)$ & $5(6.7 \%)$ & $17(17.5 \%)$ & \\
\hline High N (\%) & $3(1.6 \%)$ & $1(1.3 \%)$ & $2(2.1 \%)$ & \\
\hline \multicolumn{5}{|l|}{ Marital status } \\
\hline Married N (\%) & $81(47.1 \%)$ & $24(32.0 \%)$ & $57(58.8 \%)$ & $<0.001$ \\
\hline Single N (\%) & $38(22.1 \%)$ & $17(22.7 \%)$ & $21(21.6 \%)$ & \\
\hline Divorced N (\%) & $17(9.9 \%)$ & $8(10.7 \%)$ & $9(9.3 \%)$ & \\
\hline Widowed N (\%) & $36(20.9 \%)$ & $26(34.7 \%)$ & $10(10.3 \%)$ & \\
\hline \multicolumn{5}{|l|}{ Children's number } \\
\hline Mean \pm SD & $2.77 \pm 2.62$ & $2.20 \pm 2.55$ & $3.24 \pm 2.60$ & 0.012 \\
\hline \multicolumn{5}{|l|}{ pension } \\
\hline Yes N (\%) & $19(11.1 \%)$ & $4(5.3 \%)$ & $15(15.5 \%)$ & $<0.001$ \\
\hline No N (\%) & $153(88.9 \%)$ & $71(94.7 \%)$ & $82(84.5 \%)$ & \\
\hline
\end{tabular}




\section{Continued}

\begin{tabular}{|c|c|c|c|c|}
\hline \multicolumn{5}{|l|}{ Kind of profession } \\
\hline Free N (\%) & $104(60.5 \%)$ & $30(40.0 \%)$ & $74(76.3 \%)$ & 0.048 \\
\hline Public sector N (\%) & $13(7.6 \%)$ & $2(2.7 \%)$ & $11(11.3 \%)$ & \\
\hline Private sector N (\%) & $14(8.1 \%)$ & $5(6.7 \%)$ & $9(9.3 \%)$ & \\
\hline Never had a profession $\mathrm{N}(\%)$ & $41(23.8 \%)$ & $38(50.7 \%)$ & $3(3.1 \%)$ & \\
\hline \multicolumn{5}{|l|}{ Dental problems } \\
\hline Yes N (\%) & $90(52.3 \%)$ & $29(38.7 \%)$ & $61(62.9 \%)$ & 0.002 \\
\hline No N (\%) & $82(47.7 \%)$ & $46(61.3 \%)$ & $36(37.1 \%)$ & \\
\hline \multicolumn{5}{|l|}{ Smoking } \\
\hline Yes N (\%) & $30(17.4 \%)$ & $3(4.0 \%)$ & $27(27.8 \%)$ & $<0.001$ \\
\hline No N (\%) & $142(82.6 \%)$ & $72(96.0 \%)$ & $70(72.2 \%)$ & \\
\hline \multicolumn{5}{|l|}{ Diabetes mellitus } \\
\hline Yes N (\%) & $34(19.8 \%)$ & $17(22.7 \%)$ & $17(17.5 \%)$ & 0.401 \\
\hline No N (\%) & $138(80.2 \%)$ & $58(77.3 \%)$ & $80(82.5 \%)$ & \\
\hline \multicolumn{5}{|l|}{ Hypertension } \\
\hline Yes N (\%) & $63(36.6 \%)$ & $34(45.3 \%)$ & $29(29.9 \%)$ & 0.037 \\
\hline No N (\%) & $109(63.4 \%)$ & $41(54.7 \%)$ & $68(70.1 \%)$ & \\
\hline \multicolumn{5}{|l|}{ Osteoporosis } \\
\hline Yes N (\%) & $25(14.5 \%)$ & $12(16.0 \%)$ & $13(13.4 \%)$ & 0.632 \\
\hline No N (\%) & $147(85.5 \%)$ & $63(84.0 \%)$ & $84(86.6 \%)$ & \\
\hline \multicolumn{5}{|l|}{ Anemia } \\
\hline Yes N (\%) & $4(2.3 \%)$ & $2(2.7 \%)$ & $2(2.1 \%)$ & 1.000 \\
\hline No N (\%) & $168(97.7 \%)$ & $73(97.3 \%)$ & $95(97.9 \%)$ & \\
\hline \multicolumn{5}{|l|}{ Cardiac diseases } \\
\hline Yes N (\%) & $35(20.3 \%)$ & $18(24.0 \%)$ & $17(17.5 \%)$ & 0.296 \\
\hline No N (\%) & $137(79.7 \%)$ & $57(76.0 \%)$ & $80(82.5 \%)$ & \\
\hline \multicolumn{5}{|l|}{ Medications use } \\
\hline Mean \pm SD & $1.07 \pm 1.34$ & $1.26 \pm 1.42$ & $0.91 \pm 1.27$ & 0.090 \\
\hline \multicolumn{5}{|l|}{ Physical activity level } \\
\hline Limited N (\%) & $65(37.8 \%)$ & $31(41.3 \%)$ & $34(35.1 \%)$ & 0.329 \\
\hline Moderate N (\%) & $39(22.7 \%)$ & $13(17.3 \%)$ & $26(26.8 \%)$ & \\
\hline High N (\%) & $68(39.5 \%)$ & $31(41.3 \%)$ & $37(38.1 \%)$ & \\
\hline \multicolumn{5}{|l|}{ Depression } \\
\hline Normal & $46(26.4 \%)$ & $13(17.3 \%)$ & $33(34.0 \%)$ & 0.045 \\
\hline Slight depression & $108(62.8 \%)$ & $54(72.0 \%)$ & $54(55.7 \%)$ & \\
\hline Severe depression & $18(10.5 \%)$ & $8(10.7 \%)$ & $10(10.3 \%)$ & \\
\hline \multicolumn{5}{|l|}{ Nutritional status } \\
\hline Normal & $78(45.4 \%)$ & $28(37.3 \%)$ & $50(51.5 \%)$ & 0.102 \\
\hline Risk of malnutrition & $85(49.4 \%)$ & $44(58.7 \%)$ & $41(42.3 \%)$ & \\
\hline Malnutrition & $9(5.2 \%)$ & $3(4.0 \%)$ & $6(6.2 \%)$ & \\
\hline
\end{tabular}

\subsection{Baseline Characteristics According to Cognitive Function}

Our results show that $69.8 \%$ of total simple are classed as having cognitive impairment while only $30.2 \%$ are normal in Table 2 . Cognitive impairment is more frequent among women than men in our simple $(\mathrm{P}<0.001)$. The subjects with cognitive impairment were more likely to have low education $(\mathrm{P}<0.001)$, to never practiced some profession $(\mathrm{P}=0.015)$, without pension $(\mathrm{P}=0.048)$ and to have less physical activities $((\mathrm{P}<0.001)$. The depression $(\mathrm{P}=0.012)$, and malnutrition $(\mathrm{P}=0.002)$, both were more frequent in subjects with $\mathrm{CI}$ than normal. 
Table 2. Baseline characteristics according to cognitive function.

\begin{tabular}{|c|c|c|c|c|}
\hline & $\begin{array}{c}\text { Total } \\
\mathrm{N}=172\end{array}$ & $\begin{array}{c}\text { Normal } \\
\mathrm{N}=52 \\
(30.2 \%)\end{array}$ & $\begin{array}{c}\text { Cognitive } \\
\text { impairment } \\
\mathrm{N}=120(69.8 \%)\end{array}$ & $P$ value \\
\hline \multicolumn{5}{|l|}{ Gender } \\
\hline Females N (\%) & $75(44 \%)$ & $12(23.1 \%)$ & $63(52.5 \%)$ & $<0.001$ \\
\hline Males N (\%) & $97(56 \%)$ & $40(76.9 \%)$ & $57(47.5 \%)$ & \\
\hline \multicolumn{5}{|l|}{ Age } \\
\hline Mean \pm SD & $67.53 \pm 7.53$ & $65.87 \pm 6.45$ & $68.26 \pm 7.87$ & 0.208 \\
\hline \multicolumn{5}{|l|}{ Living place } \\
\hline Free living & $96(55.8 \%)$ & $34(65.4 \%)$ & $62(51.7 \%)$ & 0.096 \\
\hline In nursing home & $76(44.2 \%)$ & $18(34.6 \%)$ & $58(48.3 \%)$ & \\
\hline \multicolumn{5}{|l|}{ Education } \\
\hline Low N (\%) & $147(85.5 \%)$ & $38(73.1 \%)$ & $109(90.8 \%)$ & $<0.001$ \\
\hline Intermediate $\mathrm{N}(\%)$ & $22(12.8 \%)$ & $13(25.0 \%)$ & $9(7.5 \%)$ & \\
\hline High N (\%) & $3(1.6 \%)$ & $1(1.9 \%)$ & $2(1.7 \%)$ & \\
\hline \multicolumn{5}{|l|}{ Marital status } \\
\hline Married N (\%) & $81(47.1 \%)$ & $32(61.5 \%)$ & $49(40.8 \%)$ & 0.065 \\
\hline Single N (\%) & $38(22.1 \%)$ & $9(17.3 \%)$ & $29(24.2 \%)$ & \\
\hline Divorced N (\%) & $17(9.9 \%)$ & $5(9.6 \%)$ & $12(10.0 \%)$ & \\
\hline Widowed N (\%) & $36(20.9 \%)$ & $6(11.5 \%)$ & $30(25.0)$ & \\
\hline \multicolumn{5}{|l|}{ Children's number } \\
\hline Mean \pm SD & $2.77 \pm 2.62$ & $2.90 \pm 2.45$ & $2.72 \pm 2.70$ & 0.575 \\
\hline \multicolumn{5}{|l|}{ Kind of profession } \\
\hline Free N (\%) & $104(60.5 \%)$ & $35(67.3 \%)$ & $69(57.5 \%)$ & 0.015 \\
\hline Public sector N (\%) & $13(7.6 \%)$ & $7(13.5 \%)$ & $6(5.0 \%)$ & \\
\hline Private sector N (\%) & $14(8.1 \%)$ & $5(9.6 \%)$ & $9(7.5 \%)$ & \\
\hline Never had a profession $\mathrm{N}(\%)$ & $41(23.8 \%)$ & $5(9.6 \%)$ & $36(30.0 \%)$ & \\
\hline \multicolumn{5}{|l|}{ Pension } \\
\hline Yes N (\%) & $19(11.1 \%)$ & $11(21.2 \%)$ & $8(6.7 \%)$ & 0.005 \\
\hline No N (\%) & $153(88.9 \%)$ & $41(78.8 \%)$ & $112(93.3 \%)$ & \\
\hline \multicolumn{5}{|l|}{ Dental problems } \\
\hline Yes N (\%) & $90(52.3 \%)$ & $22(42.3 \%)$ & $68(56.7 \%)$ & 0.083 \\
\hline No N (\%) & $82(47.7 \%)$ & $30(57.7 \%)$ & $52(43.3 \%)$ & \\
\hline \multicolumn{5}{|l|}{ Smoking } \\
\hline Yes N (\%) & $30(17.4 \%)$ & $8(15.4 \%)$ & $22(18.3 \%)$ & 0.640 \\
\hline No N (\%) & $142(82.6 \%)$ & $44(84.6 \%)$ & $98(81.7 \%)$ & \\
\hline \multicolumn{5}{|l|}{ Alcohol consumption } \\
\hline Yes N (\%) & $3(1.7 \%)$ & $1(1.9 \%)$ & $2(1.7 \%)$ & 1.000 \\
\hline No N (\%) & $169(98.3 \%)$ & $51(98.1 \%)$ & $118(98.3 \%)$ & \\
\hline \multicolumn{5}{|l|}{ Diabetes mellitus } \\
\hline Yes N (\%) & $34(19.8 \%)$ & $10(19.2 \%)$ & $24(20 . \%)$ & 0.907 \\
\hline No N (\%) & $138(80.2 \%)$ & $42(80.8 \%)$ & $96(80.0 \%)$ & \\
\hline \multicolumn{5}{|l|}{ Hypertension } \\
\hline Yes N (\%) & $63(36.6 \%)$ & $18(34.6 \%)$ & $45(37.5 \%)$ & 0.718 \\
\hline No N (\%) & $109(63.4 \%)$ & $34(65.4 \%)$ & $75(62.5 \%)$ & \\
\hline \multicolumn{5}{|l|}{ Osteoporosis } \\
\hline Yes N (\%) & $25(14.5 \%)$ & $6(11.5 \%)$ & $19(15.8 \%)$ & 0.463 \\
\hline No N (\%) & $147(85.5 \%)$ & $46(88.5 \%)$ & $101(84.2 \%)$ & \\
\hline \multicolumn{5}{|l|}{ Anemia } \\
\hline Yes N (\%) & $4(2.3 \%)$ & $2(3.8 \%)$ & $2(1.7 \%)$ & 0.585 \\
\hline No N (\%) & $168(97.7 \%)$ & $50(96.2 \%)$ & $118(98.3 \%)$ & \\
\hline
\end{tabular}




\section{Continued}

\begin{tabular}{ccccc}
\hline Cardiac diseases & & & & \\
Yes N (\%) & $35(20.3 \%)$ & $7(13.5 \%)$ & $28(23.3 \%)$ & 0.140 \\
No N (\%) & $137(79.7 \%)$ & $45(86.5 \%)$ & $92(76.7 \%)$ & \\
Medications use & & & & \\
Mean \pm SD & $1.07 \pm 1.34$ & $1.08 \pm 1.34$ & $1.06 \pm 1.35$ & 0.792 \\
physical activity level & & & & \\
Low N (\%) & $65(37.8 \%)$ & $12(23.1 \%)$ & $53(44.2 \%)$ & $<0.001$ \\
Moderate N (\%) & $39(22.7 \%)$ & $22(42.3 \%)$ & $17(14.2 \%)$ & \\
High N (\%) & $68(39.5 \%)$ & $18(34.6 \%)$ & $50(41.7 \%)$ & \\
Depression & & & $25(20.8 \%)$ & \\
Normal & $46(26.4 \%)$ & $21(40.4 \%)$ & $79(65.8 \%)$ & 0.012 \\
Slight depression & $108(62.8 \%)$ & $29(55.8 \%)$ & $16(13.3 \%)$ & \\
Severe depression & $18(10.5 \%)$ & $2(3.8 \%)$ & & \\
nutritional status & & & & \\
Normal & $78(45.4 \%)$ & $34(65.4 \%)$ & $44(36.7 \%)$ & 0.002 \\
Risk of malnutrition & $85(49.4 \%)$ & $16(30.8 \%)$ & $69(57.5 \%)$ & \\
Malnutrition & $9(5.2 \%)$ & $2(3.8 \%)$ & $7(5.8 \%)$ & \\
\hline
\end{tabular}

\subsection{Multivariate Analysis}

The binary logistic regression assessed in Table 3 showed that the malnutrition $(\mathrm{OR}=3.03,95 \% \mathrm{CI}: 1.34-6.85)$, gender $(\mathrm{OR}=2.22,95 \% \mathrm{CI}: 1.03-5.71)$ and low education ( $\mathrm{OR}=8.35,95 \% \mathrm{CI}: 1.32-52.83)$ were risk factors for cognitive impairment, when average level of physical activity (OR $=0.19,95 \%$ CI: 0.06 0.54 ) was a protective factor compared to the limited level.

\section{Discussion}

This study was a cross-sectional study conducted among three nursing homes and one health center in three localized in north-west of morocco for one purpose to determine the relationship between malnutrition and cognitive function. Mild cognitive impairment (MCI) is a transitional state in which people who suffer from it have a higher risk of progression to dementia within 5 years [31]. The rat prevalence of cognitive impairment in our study was $69.8 \%$ and it's higher than other similar studies [32] [33]. This higher prevalence could be explained by the higher number of individuals with low education, $85.5 \%$ against almost $68 \%$ and $40 \%$ respectively in the studies mentioned above. In study of Kurkcu et al., among 475 patients who visited the geriatric outpatient department of a Dutch hospital between 2005 and 2010 the prevalence of CI was 53.2 when the low education was found only in $31 \%$ for the total simple [28]. Saghafi-Asl, and Vaghef-Mehrabany, in their case-control, age- and gender-matched study in Tabriz (East Azarbaijan, Iran), elderly subjects aged 65 years and older were recruited from nursing homes $(\mathrm{N}=76)$ and community $(\mathrm{N}=88)$ [34]. Of the total simple $70.7 \%$ were Illiterate and $76.8 \%$ had score on MMSE below 24 point. Other explanation could be given to the higher prevalence of $\mathrm{CI}$ in our results is that the majority of simple subjects were recruited in tow cities (Kenitra and Sidi Kacem City) known to have low income for their habitat. In our 
Table 3. Binary logistic regression for subjects with cognitive impairment.

\begin{tabular}{cccc}
\hline & ORa & CI 95\% & P-value \\
\hline $\begin{array}{c}\text { MNA } \\
\text { Malnutrition vs. normal } \\
\text { Gender }\end{array}$ & 3.03 & {$[1.34-6.85]$} & 0.008 \\
$\begin{array}{c}\text { Females vs. males } \\
\text { Physical activity } \\
\text { Average vs. limited } \\
\text { Education } \\
\text { Limited vs. high }\end{array}$ & 2.22 & {$[1.03-5.71]$} & 0.043 \\
\end{tabular}

ORa: adjusted odds ratio; CI: confidence interval.

study $88.9 \%$ had no pension and we found a significantly association between pension and cognitive function $(\mathrm{P}=0.005)$ in fact low income can indirectly affect cognitive function by affecting nutritional status of subject by limiting their capacity to buy aliments in terms of quality and quantity.

The objective of the present study was to determine the relationship between malnutrition and cognitive function. In multivariate regression analysis, the malnutrition was a risk factor for $\mathrm{CI}(\mathrm{OR}=3.03,95 \% \mathrm{CI}$ : 1.34 - 6.85). This result was similar to other cross-sectional study performed by El Zoghbi et al., in three long-stay elderly institutions in Beirut among 111 elderly (55 men and 56 women), malnutrition $(\mathrm{ORa}=3.03$; 95\% CI $[1.41-6.53])$ and low education $(\mathrm{ORa}=$ 1.72; $95 \%$ CI $[1.16-2.56])$ were the only risk factors for cognitive impairment [6]: Similar other study performed by Hai et al., among Five hundred eighty elderly residents aged 90 years or more in china. In the multivariate model, malnutrition $(\mathrm{OR}=4.24,95 \% \mathrm{CI}: 1.89$ - 9.52) was the risk factor for cognitive impairment after adjustment for other confounders factors [24].

Aging outside of the presence of pathology, is often accompanied by loss of appetite caused by disturbance of taste and smell which lead to changes in eating behavior with a decrease in total energy intake and more particularly a reduction in protein and fat intake [35] [36]. When lipids are essentials elements of axons myelination ( $78 \%-81 \%$ of the dry weight) involved in the nerve impulses transmission [37]. MUFA (monounsaturated fatty acids) is rich in olive oil, nuts, avocado and PUFA (polyunsaturated fatty acids) can be found mostly in fish and nuts. MUFA and PUFA are both important elements for brain function. Number of cross-sectional and longitudinal studies has confirmed the link between MUFA, PUFA intake and cognitive function and that both could play a protective effect against cognitive decline [38] [39] [40] [41]. Moreover the brain has high energy requirements, since this cerebral orange represents only $2 \%$ of the total body mass, consumes $20 \%$ of the oxygen and $25 \%$ of the glucose consumed by the total human body [42].

The brain is a complex organ with high metabolism which by aging becomes more vulnerable to oxidative stress. Vitamin B-9, B-12 and vitamin E are most recognized to act as anti-oxidative stress process. Vitamin B-9 which exist in a variety of plant foods and vitamin B-12 that can be found exclusively in animal 
foods are found in some studies not all to have link in slowing cognitive decline by supplementation or dietary intake. Likewise, Morris, MC and all found that persons in the highest quintile of total vitamin $\mathrm{E}$ intake had a $36 \%$ reduction in the rate of decline in cognitive score tests [43]. Vitamin $\mathrm{E}$ is found in a variety of green vegetables, nuts and seed oil to have antioxidant and anti-inflammatory properties [44].

The multivariate analysis showed that low education ( $\mathrm{OR}=8.35,95 \% \mathrm{CI}: 1.32$ 52.83), was risk factor for cognitive impairment and physical activity $(\mathrm{OR}=0.19$, 95\% CI: 0.06 - 0.54), was a protective factor. El Zoghbi et al. also found that education was risk factor for $\mathrm{CI}$ in multivariate analysis [6]. In fact it is not still clear whether education affect cognitive function or cognitive score of MMSE, further study taking into account education, gender and age in cut-off classification is needed. Physical activity induces structural and functional changes in the brain that could have biological and psychological benefits [45]. Lochbaum had demonstrated that aerobically trained or active participants performed significantly better on the fluid intelligence task than aerobically untrained or inactive participants [46].

This study has some limitations: our simple size is small and as mentioned above we did not take into account sex, age and education different in cut-off classification which could classed some normal illiterate persons as having CI. Furthermore the kinds of cross-sectional study don't take the association between cognitive function and nutritional status according to time. Further studies among a large simple taking into account these limitations are needed to confirm our results.

\section{Conclusion}

Our study supports past literature that malnutrition and low level of physical activity are risk factors of cognitive impairment. These indicate that nutritional status monitoring and the practice of regular physical activities can prevent it from leading to Alzheimer's disease.

\section{Conflicts of Interest}

The authors declare no conflicts of interest regarding the publication of this paper.

\section{References}

[1] HCP (2018) Les projections de la population et des ménages entre 2014 et 2050. Site institutionnel du Haut-Commissariat au Plan du Royaume du Maroc.

https://www.hcp.ma/Les-projections-de-la-population-et-des-menages-entre-2014et-2050_a1920.html

[2] de Jaeger, C. and Cherin, P. (2011) Les théories du vieillissement. Médecine \& Longévité, 3, 155-174. https://doi.org/10.1016/j.mlong.2011.10.001

[3] Malara, A., Sgrò, G., Caruso, C., Ceravolo, F., Curinga, G., Renda, G.F., Spadea, F., Garo, M. and Rispoli, V. (2014) Relationship between Cognitive Impairment and 
Nutritional Assessment on Functional Status in Calabrian Long-Term-Care. Clinical Interventions in Aging, 9, 105-110.

[4] Shi, R., Duan, J., Deng, Y., Tu, Q., Cao, Y., Zhang, M., Zhu, Q. and Lü, Y. (2015) Nutritional Status of an Elderly Population in Southwest China: A Cross-Sectional Study Based on Comprehensive Geriatric Assessment. The Journal of Nutrition, Health \& Aging, 19, 26-32. https://doi.org/10.1007/s12603-014-0471-y

[5] van der Schueren, B., van Marian, A.E., Lonterman-Monasch, S., de Vries, O.J., Danner, S.A., Kramer, M.H.H. and Muller, M. (2013) Prevalence and Determinants for Malnutrition in Geriatric Outpatients. Clinical Nutrition, 32, 1007-1011. https://doi.org/10.1016/j.clnu.2013.05.007

[6] El Zoghbi, M., Boulos, C., Amal, A.H., Saleh, N., Awada, S., Rachidi, S., Bawab, W. and Salameh, P. (2013) Association between Cognitive Function and Nutritional Status in Elderly: A Cross-Sectional Study in Three Institutions of Beirut-Lebanon. Geriatric Mental Health Care, No. 4, 73-81. https://doi.org/10.1016/j.gmhc.2013.04.007

[7] Hirose, T., Hasegawa, J., Izawa, S., Enoki, H., Suzuki, Y. and Kuzuya, M. (2014) Accumulation of Geriatric Conditions Is Associated with Poor Nutritional Status in Dependent Older People Living in the Community and in Nursing Homes: Geriatric Conditions Associated with Malnutrition. Geriatrics \& Gerontology International, 14, 198-205. https://doi.org/10.1111/ggi.12079

[8] Raynaud-Simon, A., Revel-Delhom, C. and Hébuterne, X. (2011) Clinical Practice Guidelines from the French Health High Authority: Nutritional Support Strategy in Protein-Energy Malnutrition in the Elderly. Clinical Nutrition, 30, 312-319. https://doi.org/10.1016/j.clnu.2010.12.003

[9] Torres, M. (2014) Statut nutritionnel de la personne âgée vivant à domicile: Prévalence, facteurs associés et conséquences. Université de Bordeaux, Phdthesis.

[10] Laursen, P. (1997) The Impact of Aging on Cognitive Functions. An 11-Year Follow-up Study of Four Age Cohorts. Acta Neurologica Scandinavica. Supplementum, 172, 7-86.

[11] Larrieu, S., Letenneur, L., Orgogozo, J.M., Fabrigoule, C., Amieva, H., Le Carret, N., Barberger-Gateau, P. and Dartigues, J.F. (2002) Incidence and Outcome of Mild Cognitive Impairment in a Population-Based Prospective Cohort. Neurology, 59, 1594-1599. https://doi.org/10.1212/01.WNL.0000034176.07159.F8

[12] El Kadmiri, N., Hamzi, K., El Moutawakil, B., Slassi, I. and Nadifi, S. (2013) Les aspects génétiques de la maladie d'Alzheimer (Revue). Pathologie Biologie, 61, 228-238. https://doi.org/10.1016/j.patbio.2013.04.001

[13] Perrin, R.J., Fagan, A.M. and Holtzman, D.M. (2009) Multimodal Techniques for Diagnosis and Prognosis of Alzheimer's Disease. Nature, 461, 916-922. https://doi.org/10.1038/nature08538

[14] Guyant-Maréchal, L., Campion, D. and Hannequin, D. (2009) Génétique de la maladie d'Alzheimer: Formes autosomiques dominantes. Revue Neurologique, 165, 223-231. https://doi.org/10.1016/j.neurol.2008.10.019

[15] Foubert-Samier, A. and Goizet, C. (2010) Génétique et maladie d'Alzheimer. Neurologie, 2, 194-196.

[16] St. George-Hyslop, P. (1995) Genetic Determinants of Alzheimer Disease. Progress in Clinical and Biological Research, 393, 139-145.

[17] Saunders, A.M., Strittmatter, W.J., Schmechel, D., St. George-Hyslop, P.H., Pericak-Vance, M.A., Joo, S.H., Rosi, B.L., et al. (1993) Association of Apolipoprotein E Allele 4 with Late-Onset Familial and Sporadic Alzheimer's Disease. Neurology, 43, 
1467-1467. https://doi.org/10.1212/WNL.43.8.1467

[18] Lamour, Y. (1994) Physiopathologie de la maladie d'Alzheimer. La Revue de Médecine Interne, 15, 41s-44s.

[19] Spaccavento, S., Del Prete, M., Craca, A. and Fiore, P. (2009) Influence of Nutritional Status on Cognitive, Functional and Neuropsychiatric Deficits in Alzheimer's Disease. Archives of Gerontology and Geriatrics, 48, 356-360. https://doi.org/10.1016/j.archger.2008.03.002

[20] Solfrizzi, V., Panza, F., Frisardi, V., Seripa, D., Logroscino, G., Imbimbo, B.P. and Pilotto, A. (2011) Diet and Alzheimer's Disease Risk Factors or Prevention: The Current Evidence. Expert Review of Neurotherapeutics, 11, 677-708. https://doi.org/10.1586/ern.11.56

[21] Anthony, J.C., Le Resche, L., Niaz, U., Von Korff, M.R. and Folstein, M.F. (1982) Limits of the "Mini-Mental State" as a Screening Test for Dementia and Delirium among Hospital Patients. Psychological Medicine, 12, 397. https://doi.org/10.1017/S0033291700046730

[22] Derouesné, C., Poitreneau, J., Hugonot, L., Kalafat, M., Dubois, B. and Laurent, B. (1999) Le Mini-Mental State Examination (MMSE): Un outil pratique pour l'évaluation de l'état cognitif des patients par le clinician. 8.

[23] Li, Y., Fang, X., Zhao, W.-G., Chen, Y. and Hu, S.-L. (2017) A Risk Factor Analysis of Cognitive Impairment in Elderly Patients with Chronic Diseases in a Chinese Population. Medical Science Monitor. International Medical Journal of Experimental and Clinical Research, 23, 4549-4558. https://doi.org/10.12659/MSM.904254

[24] Hai, S., Cao, L., Yang, X., Wang, H., Liu, P., Hao, Q.K. and Dong, B.R. (2017) Association between Nutrition Status and Cognitive Impairment among Chinese Nonagenarians and Centenarians. International Journal of Gerontology, 11, 215-219. https://doi.org/10.1016/j.ijge.2016.12.002

[25] Guigoz, Y., Vellas, B. and Garry, P.J. (1996) Assessing the Nutritional Status of the Elderly: The Mini Nutritional Assessment as Part of the Geriatric Evaluation. Nutrition Reviews, 54, S59-S65. https://doi.org/10.1111/j.1753-4887.1996.tb03793.x

[26] Kondrup, J. (2003) ESPEN Guidelines for Nutrition Screening 2002. Clinical Nutrition, 22, 415-421. https://doi.org/10.1016/S0261-5614(03)00098-0

[27] Guigoz, Y., Vellas, B. and Garry, P.J. (1997) Facts, Research and Intervention in Gerontology. In: The Mini Nutritional Assessment. A Practical Assessment Tool for Grading the Nutritional State of Elderly Persons, 3rd Edition, Serdi Publishing Company, Paris, 15-60.

[28] Kurkcu, M., Meijer, R.I., Lonterman, S., Muller, M. and de van der Schueren, M.A.E. (2018) The Association between Nutritional Status and Frailty Characteristics among Geriatric Outpatients. Clinical Nutrition ESPEN, 23, 112-116. https://doi.org/10.1016/j.clnesp.2017.11.006

[29] Armstrong, T. and Bull, F. (2006) Development of the World Health Organization Global Physical Activity Questionnaire (GPAQ). Journal of Public Health, 14, 66-70. https://doi.org/10.1007/s10389-006-0024-x

[30] Bae, S., Shimada, H., Park, H., Lee, S., Makizako, H., Doi, T., Yoshida, D., Tsutsumimoto, K., Anan, Y. and Suzuki, T. (2017) Association between Body Composition Parameters and Risk of Mild Cognitive Impairment in Older Japanese Adults: Body Composition and MCI. Geriatrics \& Gerontology International, 17, 2053-2059. https://doi.org/10.1111/ggi.13018

[31] Hamrik, Z., Sigmundová, D., Kalman, M., Pavelka, J. and Sigmund, E. (2014) Physical Activity and Sedentary Behaviour in Czech Adults: Results from the GPAQ 
Study. European Journal of Sport Science, 14, 193-198. https://doi.org/10.1080/17461391.2013.822565

[32] Muscari, A., Spiller, I., Bianchi, G., Fabbri, E., Forti, P., Magalotti, D., Pandolfi, P. and Zoli, M. (2018) Predictors of Cognitive Impairment Assessed by Mini Mental State Examination in Community-Dwelling Older Adults: Relevance of the Step Test. Experimental Gerontology, 108, 69-76. https://doi.org/10.1016/j.exger.2018.03.021

[33] Noh, H.-M., Oh, S., Song, H.J., Lee, E.Y., Jeong, J.-Y., Ryu, O.-H., Hong, K.-S. and Kim, D.-H. (2017) Relationships between Cognitive Function and Body Composition among Community-Dwelling Older Adults: A Cross-Sectional Study. BMC Geriatrics, 17, 259. https://doi.org/10.1186/s12877-017-0651-9

[34] Saghafi-Asl, M. and Vaghef-Mehrabany, E. (2017) Comprehensive Comparison of Malnutrition and Its Associated Factors between Nursing Home and Community Dwelling Elderly: A Case-Control Study from Northwestern Iran. Clinical Nutrition ESPEN, 21, 51-58. https://doi.org/10.1016/j.clnesp.2017.05.005

[35] McGee, M. and Jensen, G.L. (2000) Nutrition in the Elderly. Journal of Clinical Gastroenterology, 30, 372-380. https://doi.org/10.1097/00004836-200006000-00005

[36] Sjögren, A., Österberg, T. and Steen, B. (1994) Intake of Energy, Nutrients and Food Items in a Ten-Year Cohort Comparison and in a Six-Year Longitudinal Perspective: A Population Study of 70- and 76-Year-Old Swedish People. Age and Ageing, 23, 108-112. https://doi.org/10.1093/ageing/23.2.108

[37] O’Brien, J.S. and Lois Sampson, E. (1965) Lipid Composition of the Normal Human Brain: Gray Matter, White Matter, and Myelin. Journal of Lipid Research, 6, 537-544.

[38] Solfrizzi, V., Panza, F., Torres, F., Mastroianni, F., Del Parigi, A., Venezia, A. and Capurso, A (1999) High Monounsaturated Fatty Acids Intake Protects against Age-Related Cognitive Decline. Neurology, 52, 1563-1569. https://doi.org/10.1212/WNL.52.8.1563

[39] Naqvi, A.Z., Harty, B., Mukamal, K.J., Stoddard, A.M., Vitolins, M. and Dunn, J.E. (2011) Monounsaturated, Trans \& Saturated Fatty Acids and Cognitive Decline in Women. Journal of the American Geriatrics Society, 59, 837-843. https://doi.org/10.1111/j.1532-5415.2011.03402.x

[40] Baierle, M., Vencato, P., Oldenburg, L., Bordignon, S., Zibetti, M., Trentini, C., Duarte, M., et al. (2014) Fatty Acid Status and Its Relationship to Cognitive Decline and Homocysteine Levels in the Elderly. Nutrients, 6, 3624-3640. https://doi.org/10.3390/nu6093624

[41] Bo, Y.C., Zhang, X.Y., Wang, Y.L., You, J., Cui, H., Zhu, Y.W., Pang, W., Liu, W., Jiang, Y.G. and Lu, Q.J. (2017) The N-3 Polyunsaturated Fatty Acids Supplementation Improved the Cognitive Function in the Chinese Elderly with Mild Cognitive Impairment: A Double-Blind Randomized Controlled Trial. Nutrients, 9, 54. https://doi.org/10.3390/nu9010054

[42] Bélanger, M., Allaman, I. and Magistretti, P.J. (2011) Brain Energy Metabolism: Focus on Astrocyte-Neuron Metabolic Cooperation. Cell Metabolism, 14, 724-738. https://doi.org/10.1016/j.cmet.2011.08.016

[43] Morris, M.C., Evans, D.A., Bienias, J.L., Tangney, C.C. and Wilson, R.S. (2002) Vitamin E and Cognitive Decline in Older Persons. Archives of Neurology, 59, 1125-1132. https://doi.org/10.1001/archneur.59.7.1125

[44] Oyarce, K., Bongarzone, E.R. and Nualart, F. (2014) Unconventional Neurogenic Niches and Neurogenesis Modulation by Vitamins. Journal of Stem Cell Research \& Therapy, 4, 184. 
[45] Mandolesi, L., Polverino, A., Montuori, S., Foti, F., Ferraioli, G., Sorrentino, P. and Sorrentino, G. (2018) Effects of Physical Exercise on Cognitive Functioning and Wellbeing: Biological and Psychological Benefits. Frontiers in Psychology, 9, 509. https://doi.org/10.3389/fpsyg.2018.00509

[46] Lochbaum, M.R., Karoly, P. and Landers, D.M. (2002) Evidence for the Importance of Openness to Experience on Performance of a Fluid Intelligence Task by Physically Active and Inactive Participants. Research Quarterly for Exercise and Sport, 73, 437-444. https://doi.org/10.1080/02701367.2002.10609043 